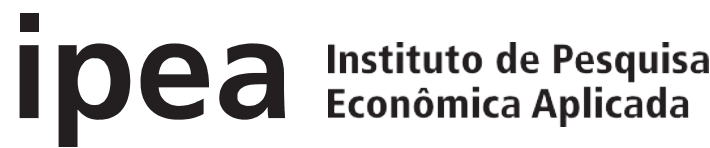

\section{Título do capítulo \\ Autores(as) \\ DOI}

\section{Título do livro \\ Organizadores(as)}

\section{Volume}

\section{Série}

\section{Cidade}

Editora

Ano
Edição
ISBN
DOI

CAPÍTULO 3 - PAPEL DA UNIÃO NA COORDENAÇÃO FEDERATIVA DA POLIITICA DE EDUCAÇÃO BÁSICA

\section{Marta Wendel Abramo}

Elaine Cristina Licio

http://dx.doi.org/10.38116/978-65-5635-005-9/cap3

COORDENAÇÃO E RELAÇÕES INTERGOVERNAMENTAIS NAS POLÍTICAS SOCIAIS BRASILEIRAS

Luciana Jaccoud

Brasilia

Instituto de Pesquisa Econômica Aplicada (Ipea)

2020

978-65-5635-005-9

http://dx.doi.org/10.38116/978-65-5635-005-9

As publicações do Ipea estão disponíveis para download gratuito nos formatos PDF (todas) e EPUB (livros e periódicos). Acesse: http://www.ipea.gov.br/portal/publicacoes

As opiniões emitidas nesta publicação são de exclusiva e inteira responsabilidade dos autores, não exprimindo, necessariamente, o ponto de vista do Instituto de Pesquisa Econômica Aplicada ou do Ministério da Economia.

É permitida a reprodução deste texto e dos dados nele contidos, desde que citada a fonte. Reproduções para fins comerciais são proibidas. 



\title{
PAPEL DA UNIÃO NA COORDENAÇÃO FEDERATIVA DA POLÍTICA DE EDUCAÇÃO BÁSICA
}

\author{
Marta Wendel Abramo \\ Elaine Cristina Licio
}

\section{INTRODUÇÃO}

Este capítulo analisa a evolução do papel desempenhado pela União como ente responsável pela coordenação federativa da educação básica no Brasil, tendo em vista os objetivos de expansão da universalização e equalização do acesso ao ensino obrigatório colocados pelas reformas educacionais realizadas nas duas últimas décadas. Verifica-se, nesse período, um crescente comprometimento e corresponsabilização do governo federal com os objetivos e resultados desse nível de ensino que, tradicionalmente, esteve sob o protagonismo dos governos subnacionais.

A ampliação do papel da União enquanto coordenadora de políticas sociais não é exclusividade da política educacional. Os propósitos de universalização e equidade que inspiram a Constituição Federal de 1988 (CF/1988) inauguraram uma nova etapa nas políticas sociais, introduzindo objetivos que pressupóem a construçáo de políticas nacionais implementadas de forma coordenada pelos entes federativos. No entanto, o mesmo texto constitucional instituiu um regime descentralizado, com responsabilidades compartilhadas, que não distribuiu claramente as parcelas de competências entre as esferas de governo. Esse sistema de repartição de receitas e competências limita a capacidade de coordenação de políticas pelo governo federal, gerando competição intergovernamental e abrindo espaço para a manutenção de desigualdades e para o desenvolvimento não equitativo das políticas sociais no território brasileiro (Arretche, 2004; 2012). Tais aspectos tensionam o federalismo e trazem à tona seus elementos aparentemente contraditórios: autonomia e unidade; uniformidade e diversidade.

A descentralização fiscal preconizada pela CF/1988 trouxe como consequência, em um primeiro momento, a limitação da capacidade de gasto do governo federal. A partir de então, os municípios passaram a contar não apenas com autonomia fiscal, mas também autonomia política e capacidade de tomar decisóes próprias na condução de várias políticas. Sobre esse período, Abrucio (2005) ressalta a conformação de um tipo de "federalismo compartimentalizado", na medida em que a União se desincumbiu do seu papel coordenador e cada nível de governo buscou atuar de maneira independente, dados os poucos incentivos à atuação conjunta e o estabelecimento de um "jogo de empurra" entre as esferas de governo. Esse cenário 
começou a mudar na segunda metade da década de 1990, dentre outros fatores, mediante a estabilização econômica, desvinculação dos gastos/transferências da União e o aumento das contribuiçôes sociais (Abrucio, 2005). Arretche (2002) avalia que, com essa estratégia, a União garantiu para si recursos voltados para a área social, além de recuperar parte das receitas perdidas na partilha fiscal feita pela CF/1988. Foi a partir de então que a Uniáo gradualmente estabeleceu seu papel coordenador no processo de descentralização das políticas sociais, favorecendo a cooperação de estados e municípios para com os seus objetivos de reforma.

$\mathrm{Na}$ educação, o desafio de coordenação federativa é mais sensível que nas demais políticas universais, dado que sua organização pressupóe a coexistência de sistemas independentes, distribuídos entre os três níveis de governo, e que devem atuar mediante um regime de colaboração. A adoção de um sistema múltiplo - e não único, como no caso da saúde e assistência social - aporta desafios peculiares. A Constituição Federal não detalhou inicialmente o arranjo institucional adequado para compatibilizar autonomia e colaboração e também não forneceu instrumentos adequados para tanto. Embora tenha previsto a elaboração de um Plano Nacional de Educação que integrasse as açóes do poder público em torno de objetivos comuns (art. 214), o texto constitucional original não atribuiu claramente ao governo central uma competência coordenativa, reservando para este a atribuição de normatização geral e a prestação de assistência técnica e financeira aos entes federados para atendimento à escolaridade obrigatória - então considerada apenas o ensino fundamental.

Procurou-se suprir essa lacuna com alteraçóes constitucionais posteriores. As reformas educacionais implementadas nas duas últimas décadas atribuíram, de forma mais clara, à União a responsabilidade de coordenar a política de educação, legitimando sua atuação com vistas a alcançar os objetivos de universalização do acesso, equalização de oportunidades educacionais e garantia de um padrão mínimo de qualidade em todo o território nacional. No entanto, apesar de as mudanças constitucionais na organização da política de educação apresentarem um caráter progressivo, podemos identificar dois momentos distintos de atuação do governo federal em função dos objetivos delimitados pelas duas reformas principais consideradas na presente análise.

Um primeiro período, iniciado com a Emenda Constitucional (EC) no 14/1996, teve como objetivo assegurar a universalização do ensino fundamental, ${ }^{1}$ no qual a coordenação federal ganhou suas bases normativas por meio de duas alteraçóes principais: i) a maior definição das responsabilidades dos três níveis de governo na gestão da política; e ii) a criaçáo do Fundo de Desenvolvimento e Manutenção do Ensino Fundamental e Valorizaçáo do Magistério (Fundef),

1. Conforme art. 60 do Ato das Disposições Constitucionais Transitórias da CF/1988. 
importante instrumento de coordenação criado a partir de mudanças nos critérios de repartição de receitas com vistas a reduzir desigualdades no gasto por aluno. A coordenação implementada pela União a partir de entáo teve como foco a criação dos fundamentos normativos para sua atuação num campo até então dominado pelos governos subnacionais.

No segundo período, iniciado com a EC no 53/2006, a reforma ampliou seu foco para a educação infantil e o ensino médio, expandindo os critérios de financiamento do Fundef para toda a educação básica, ${ }^{2}$ na forma do Fundo de Manutenção e Desenvolvimento da Educação Básica e de Valorização dos Profissionais da Educação (Fundeb). Todavia, diferentemente do seu antecessor, este fundo não se propunha, naquele momento, a assegurar a universalização da educação básica, remetendo ao Plano Nacional de Educação a definição das respectivas metas de universalização. ${ }^{3}$ Coube à EC no 59/2009 tornar a educação básica obrigatória ampliando, para tanto, o aporte de recursos da Uniáo - mediante a desvinculação das receitas da Uniâo. Nesse segundo período, a União passou a ocupar um papel mais central na coordenação da política, diversificando e ampliando os instrumentos de coordenação federativa que já haviam sido mobilizados no período anterior e ampliando sua função supletiva e redistributiva na condução de uma política nacional.

Mas ao que nos referimos quando tratamos do tema coordenação federativa? Quais seus objetivos e de que forma pode ser operacionalizada? Segundo Souza (2018), a coordenação federativa pode ser entendida como a organização de atividades, com o objetivo de alcançar consenso entre indivíduos e organizaçóes para o atingimento dos objetivos de um grupo. Araújo (2010), por sua vez, distingue a coordenação da colaboração federativa a partir das dimensōes verticais e horizontais das relaçôes intergovernamentais: enquanto a primeira pressupóe uma hierarquia do nível de governo que a conduz, a colaboração abrangeria também as relações entre governos do mesmo nível. Para fins deste texto, entendemos que a colaboração federativa coincide com o conceito de cooperação no sentido de sinalizar a atuação discricionária e voluntária dos entes do mesmo ou de diferentes níveis de governo visando ao benefício mútuo. Dessa forma, a cooperação/colaboração federativa operam no campo da autonomia que os entes possuem para decidir sobre a articulação ou não com as iniciativas dos demais. Já a coordenação aponta para uma relaçấo hierárquica dos níveis de governo de maior abrangência, ainda que essa subordinação tenha como pressuposto o consenso estabelecido a partir do texto constitucional que rege a Federação.

2. A educação básica engloba além do ensino fundamental, a pré-escola e o ensino médio, nos termos do art. 4, I da LDB. 3. Ver nova redação dada ao art. 60, inciso III, ADCT (CF/1988) pela EC ํㅡ 53/2006. 
Souza (2018) observa que a coordenação não é espontânea, devendo ser construída, o que demanda a proposição de incentivos que tornem racional a adesão dos participantes da política e de suas agências. Ou seja, quem coordena deve mobilizar instrumentos que atraiam os demais partícipes, a fim de criar maior coerência e reduzir redundâncias, lacunas e contradiçóes na gestão de determinada política. No caso das políticas nacionais, o exercício da função coordenadora por parte do governo central exige enfim a adoção de um sistema de incentivos capaz de influenciar a agenda dos governos subnacionais (Souza, 2005; Arretche, 2011; 2004).

Ao analisar o fortalecimento do papel da União enquanto coordenadora da política de educação básica, argumentamos que as reformas implementadas após a CF/1988 ampliaram seu espaço de atuação na política e permitiram a mobilização de instrumentos de coordenação para alcançar um patamar cada vez mais elevado do direito à educação. Diante disso, nossa hipótese é de que, embora progressivo e incremental, esse processo apresentou também elementos de inflexão, refletindo, em última análise, uma alteração na concepção das políticas sociais e do papel do Estado. Para investigá-la, nosso objeto de análise consiste nos instrumentos de coordenaçáo mobilizados pela União a partir das duas reformas educacionais descritas - em especial aqueles direcionados para partilha dos recursos (Fundef e Fundeb), os Planos Nacionais de Educação e o Plano de Desenvolvimento da Educação (PDE) - escolhidos por melhor refletirem a concepção de coordenação federativa do governo federal em cada período. ${ }^{4}$ Buscamos compreender o alcance e desenho desses instrumentos em um contexto mais amplo que determinou sua criação, ampliaçáo ou, ainda, eventuais adequaçóes à luz das alteraçóes nas diretrizes governamentais refletidas nas reformas constitucionais abordadas.

Para tanto, o texto se divide em quatro partes além dessa introdução e da conclusáo. Na segunda parte, discutimos como se dá o processo de mudança nas políticas públicas e como a escolha dos respectivos instrumentos não são neutras, refletindo as opçóes políticas de seus formuladores. Na terceira parte, apresentamos como o texto constitucional original de 1988 (náo) enfrentou o tema da coordenação federal na política de educação. Na quarta parte, analisamos a coordenação federativa a partir das mudanças trazidas pela EC nº 14/1996 (Fundef), que lançou os fundamentos normativos para o seu exercício pelo governo federal. A quinta parte se dedica à análise do período iniciado pela $\mathrm{EC}$ no 53/2006 (Fundeb), no qual se verifica uma ampliação efetiva do espaço de coordenação da política por parte da União com a construção de uma estrutura de incentivos apoiada em instrumentos infraconstitucionais. Ao final, sintetizamos nossas conclusóes.

4. Em alguns casos, analisaremos não apenas os normativos, mas também as exposições de motivos e os documentos oficiais que revelem os propósitos do governo federal na concepção dos instrumentos. 


\section{MUDANÇAS NAS POLÍTICAS PÚBLICAS E ESCOLHA DOS INSTRUMENTOS}

Como vimos, os arranjos de coordenação de políticas nacionais no federalismo são operados por instrumentos destinados a induzir comportamentos convergentes em um contexto marcado por autonomias dos entes. No caso brasileiro, a Constituição Federal de 1988 não só colocou o desafio de implementar políticas públicas sociais de caráter universal (principalmente na saúde e educação), como inseriu o propósito nacional de equalização das desigualdades regionais (art. 3ํㅡㄹ III). Também vale ressaltar que nosso modelo de federalismo pressupóe tanto a soberania dos entes federados para definir suas próprias políticas, quanto a busca de uniformidade na prestação de serviços sociais a fim de assegurar condiçóes homogêneas de acesso às provisóes públicas em qualquer lugar do território nacional. ${ }^{5}$

Os instrumentos de coordenação da ação governamental devem responder simultaneamente aos objetivos específicos e gerais da respectiva política pública, incluindo a redução das desigualdades, calibrando incentivos destinados a influenciar ou condicionar decisôes e promover adesão às diretrizes nacionais. Esses incentivos podem variar dentro de um mesmo Estado, de política para política ou ao longo do tempo. Sua configuração vai decorrer, em parte, de arranjos herdados de períodos anteriores e, em outra medida, da inovação na formulação e combinaçáo de instrumentos de forma a garantir a estrutura de incentivos suficientes para assegurar uma ação coordenada.

A questão que se coloca é como o ente responsável pela coordenação identifica e seleciona os instrumentos institucionais necessários para obter o comportamento desejado e garantir a cooperação intergovernamental. De acordo com Olaik e Medeiros (2011), o processo de escolha de um instrumento de ação pública comporta duas fases: uma na qual os instrumentos disponíveis seriam analisados a partir de critérios técnicos (efetividade, eficiência, equidade, capacidade de realização, legitimidade e viabilidade política) a fim de identificar aquele que dará ao programa governamental a maior probabilidade de sucesso; e outra na qual é feita uma opção política, baseada em outra sorte de critérios como: opção por uma gestão direta ou indireta, o grau de coercitividade ou flexibilidade desejado, o grau de visibilidade que o governo deseja dar à política. Assim, ao selecionar os instrumentos não se está buscando unicamente a ferramenta mais eficiente para resolver um problema, mas também se moldando a forma de fazer a política.

Ora, se os instrumentos de política pública não são apenas ferramentas técnicas de resolução de problemas, mas também carregam em si a intencionalidade dos formuladores, inovaçôes observadas nos instrumentos podem indicar uma revisão

5. Bachur (2005) em estudo comparativo entre o federalismo alemão e o americano aponta que a superação das assimetrias regionais nem sempre é um objetivo da Federação a ser perseguido pelo Estado, como se dá, por exemplo, no modelo americano em que não há uma preocupação institucional e constitucional com a equalização regional. 
da própria concepção sobre a forma de fazer política. Nesse sentido, trazemos o pensamento de Hall (1993), o qual destaca que as ideias são centrais na concepção das políticas. Para o autor, os formuladores trabalham costumeiramente dentro de um conjunto de ideias e padróes que configuram um prisma pelo qual enxergam os problemas abordados, influenciando não apenas as decisōes sobre diretrizes e instrumentos, mas também a própria natureza da política e suas soluçóes. Quando esse conjunto de ideias e padrôes se altera, temos uma mudança de paradigma, que vai impactar, por sua vez, o processo de formulação das políticas.

Ainda segundo Hall (1993), as mudanças nas políticas públicas respondem a distintos fatores - orientação do partido no governo, relaçôes entre Estado e sociedade, natureza do discurso político, impacto de eventos externos - e podem ser categorizadas em três ordens: i) na primeira, as condiçôes específicas dos instrumentos de políticas podem sofrer alteraçóes pontuais, enquanto os objetivos das políticas e a estrutura de instrumentos permanecem inalterados; ii) na segunda, tanto o contexto como os instrumentos são alterados, mas os principais objetivos permanecem estáveis; e iii) na terceira, há mudança do próprio paradigma de política e os instrumentos são revistos em função da revisão das decisóes sobre a política. As mudanças de primeira e segunda ordem podem ser entendidas como respostas às experiências passadas (erros, acertos e ajustamentos) e são tratadas como eventos ordinários e contínuos na elaboração da política, inclusive pela superação do próprio problema - ou de uma etapa - a qual a política pública se vinculava. Já as de terceira ordem envolvem alteraçōes mais profundas na política, derivadas não de um processo natural de vivência das experiências passadas, mas de uma mudança de paradigma, o que levaria a uma reorientação das diretrizes prioritárias da política e uma ressignificação dos objetivos em si, repercutindo, por fim, na alteração dos meios para sua implementação.

As sucessivas alteraçôes do art. 60 do Ato das Disposiçóes Constitucionais Transitórias (ADCT) - que define objetivos transitórios da política de educação por exemplo, refletem a evolução das respectivas diretrizes prioritárias. Dentre os objetivos inseridos neste artigo, alterados pelas reformas do Fundef e Fundeb, destacamos aqueles diretamente relacionados com a gradual ampliação do escopo das ofertas de responsabilidade dos entes federativos, sistematizados no quadro 1 .

QUADRO 1

Evolução dos objetivos transitórios da educação na CF/1988

\begin{tabular}{|l|l|}
\hline & Redação do art. 60 (ADCT) \\
\hline Texto original & $\begin{array}{l}\text { "Nos dez primeiros anos da promulgação da Constituição, o Poder Público desenvolverá esforços, com a } \\
\text { mobilização de todos os setores organizados da sociedade e com a aplicação de, pelo menos, cinquenta por } \\
\text { cento dos recursos a que se refere } 0 \text { art. } 212 \text { da Constituição, para eliminar o analfabetismo e universalizar } \\
\text { o ensino fundamental." }\end{array}$ \\
\hline
\end{tabular}




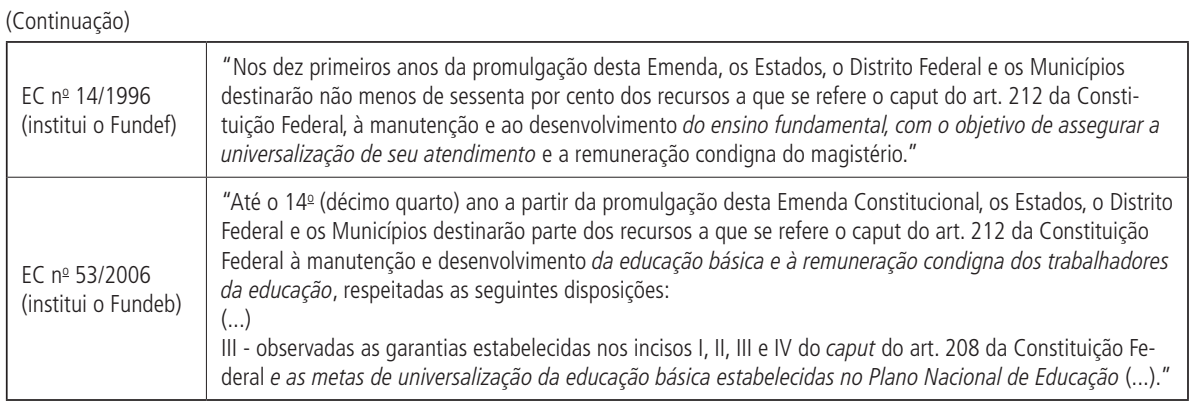

Elaboração dos autores.

Essas alteraçôes apontam para um processo de ampliação progressiva da responsabilidade do poder público perante o direito à educação, explicada, em parte, pela superação das diretrizes precedentes. Assim, uma vez alcançadas (ou praticamente alcançadas, no caso da eliminação do analfabetismo) a universalização do ensino fundamental prevista pelo texto original da CF/1988 e referendada pela Emenda Constitucional do Fundef (1996), é natural que novas metas, mais amplas, fossem desenhadas a partir das alterações efetivadas pela EC do Fundeb. No entanto, vale destacar que, embora esta última tenha direcionado os recursos do fundo para a educação básica, ela não se comprometeu nem se restringiu à sua universalização - remetendo ao Plano Nacional de Educação (PNE) a definição de metas nesse sentido. Foi apenas com a EC no 59/2009 que a educação básica (dos quatro aos dezessete anos) se tornou obrigatória (art. 208, I da CF/1988), permitindo ao texto constitucional demandar sua universalização (art. 211, $\$ 4$ ).

Analisando esse processo, Segatto e Abrucio (2016) apontam que foi no governo FHC que o governo federal passou a ter um papel de coordenador, desenvolvendo mecanismos para o aumento das matrículas no ensino fundamental e diminuição das desigualdades de gastos intraestaduais. Esse mesmo padrão seria mantido e aprofundado no governo Lula, por meio de programas e açóes que buscaram redistribuir recursos e aumentar a articulação entre os níveis de governo. Para os autores, portanto, a perspectiva apresentada é de continuidade incremental.

Gomes, Silva e Costa (2019), contudo, destacam que as decisóes tomadas em relação à educação espelham projetos políticos e que, consequentemente, mudanças do espectro político no comando do governo refletirão em uma alteração dos objetivos da política de educação. Isso advém, segundo os autores, dos princípios normativos que orientam os partidos e dos cálculos políticos das tomadas de decisão em relação às suas bases de sustentação: enquanto partidos de direita priorizariam a eficiência dos mercados, governos de esquerda tenderiam a priorizar políticas sociais que produzam efeitos redistributivos. ${ }^{6} \mathrm{Na}$ área da educação, a ampliação do papel estatal nos governos de esquerda estaria relacionada, pois, ao

6. Os autores chamam essa perspectiva de governos partidários. 
ideário redistributivista. A inflexão observada no Brasil no início do século XXI com a extensão do ensino obrigatório e a ampliação da atuação do governo federal na regulação e no financiamento dos serviços educacionais públicos se explicaria, segundo essa teoria, pelos princípios de justiça social e pela adoção de políticas equalizadoras e redistributivas. ${ }^{7}$ Castro e Ribeiro (apud Farenzena, 2011) também compartilham a opinião de que o período reflete uma inflexão na concepção de políticas sociais. Os autores apontam que o contexto de crescimento econômico e estabilidade experimentado no segundo governo Lula permitiu abandonar as estratégias de restrição do gasto social e olhar as políticas sociais como instrumento potencial de desenvolvimento e superação das crises.

Assim, ainda que as mudanças na política de educação básica observadas no Brasil no período 1996-2016 em direção à progressiva expansão do acesso à educação e novos desenhos de coordenação federativa se expliquem, em grande parte, pela superação (ou quase superação) dos principais problemas relacionados às diretrizes antecedentes (eliminação do analfabetismo e progressiva universalização do ensino fundamental). Há, ainda, alteraçóes políticas e econômicas relevantes a partir dos anos 2000 que colocaráo a questâo do gasto social e a agenda redistributiva em novo patamar e inspirarão outra sorte de mudanças nas políticas públicas.

Como já referido, a literatura sobre descentralização vem apontando que a atuação do governo central é essencial para garantir coordenaçấo e superar as disparidades sociais e regionais. Esse movimento de "refluxo" no processo de descentralização não foi exclusivo da educação e ocorreu de maneira geral nas políticas sociais brasileiras a partir, sobretudo, dos anos 2000 (Arretche, 2005; Lotta et al., 2014). Segundo Oliveira e Lotta (2014), a ampliação da coordenação federativa, ou recentralização, se vincula a dois fenômenos: o primeiro é a constatação da dificuldade da maior parte dos municípios assumirem a atribuição constitucional de implementaçáo das políticas públicas com a oferta de serviços universais de qualidade; o segundo vincula-se ao propósito de promoção da equidade e combate às diferenças, que demanda uma maior coordenação central. Assim, a busca de formas mais eficientes para enfrentar as desigualdades e construir patamares mais homogêneos de políticas públicas reforçou a necessidade de coordenação federativa e, consequentemente, o papel do governo central, impondo a revisão dos arranjos e instrumentos de coordenação.

Retomando o argumento da mudança nos instrumentos das políticas públicas, consideramos que uma primeira alteração significativa em relação ao propósito original do texto constitucional, a qual classificamos como de segunda ordem, teve como ponto de partida a EC do Fundef em 1996 que, embora não tenha provocado

7. Em artigo publicado no jornal a Folha de São Paulo, em 22 de novembro de 2009, sobre as reformas educacionais realizadas pelas ECs nºs 53 e 59, o então ministro da Educação, Fernando Haddad, vaticina que "as novas gerações hão de notar o sentido progressista em que foi reescrito o capítulo consagrado à educação em nossa lei maior". Disponível em: <encurtador.com.br/ilELV>. 
uma alteração substantiva dos objetivos constitucionais para a política de educação, detalhou as responsabilidades dos entes federativos e trouxe novos instrumentos de coordenação para alcance desses objetivos.

Argumentamos adicionalmente que o contexto de fortalecimento do poder coordenador da União no fim da década de 1990 lhe permitiu mobilizar esforços para garantir a equidade das oportunidades educacionais e um padrão mínimo de qualidade em todo o território nacional (art. 211, $\$ 1$ o da CF/1988). As mudanças implementadas pelas emendas constitucionais da década seguinte, por sua vez, vieram no sentido de não apenas ampliar as garantias da política - passando a assegurar a educação básica como um todo e não somente o ensino fundamental, com a correspondente ampliação dos recursos federais destinados - mas também refletir, a nosso ver, um novo paradigma de pensamento sobre a educação e atuação do governo federal como agente responsável pela redução de desigualdades educacionais. Nas próximas seçôes, analisamos em que medida essa mudança de paradigma orientada pelo ideário redistributivista implicou a redefiniçẫo de instrumentos e arranjos utilizados pela União para coordenação da política.

\section{COORDENAÇÃO FEDERAL NA POLÍTICA DE EDUCAÇÃO BÁSICA NO TEXTO CONSTITUCIONAL ORIGINAL}

A história da educação brasileira é marcada pela descentralização e dispersão, com limitada participação do governo central. $\mathrm{O}$ modelo, que se instalou ainda no Império, fez com que o ensino superior gratuito, dedicado às elites, ficasse sob responsabilidade do governo central, financiado com os impostos mais elevados, enquanto a instrução primária ficava a cargo das províncias, com capacidades administrativas e recursos fiscais variáveis. Esse modelo, conhecido como duplicidade de sistemas de ensino, conforme Cury (2008), deu origem a uma enorme heterogeneidade no desenvolvimento das redes educacionais, até hoje não superada. Embora combatido pelo Movimento do Manifesto dos Pioneiros da Educação Nova, esse arranjo permaneceu no período republicano e, a partir da década de 1930, permitiu que a oferta pública educacional se expandisse, sob um modelo de "hegemonia estadualista na provisão dos serviços educacionais primário e médio" (Abrucio, 2010, p. 56). Os movimentos de expansão com centralização decisória especialmente no período Vargas e no regime militar - não foram capazes de reduzir as assimetrias regionais relacionadas à cobertura, valorização dos professores ou qualidade dos serviços educacionais. Assim, historicamente, a responsabilidade pela oferta do ensino fundamental no Brasil tem sido dos estados e municípios, por meio de redes distintas e não integradas, com discreta participação federal na prestação desse serviço (Franzese, 2010). Até meados da década de 1990, a ausência de um modelo claro de coordenação federativa que conduzisse a um resultado mais uniforme e positivo das políticas sociais contribuiu para o agravamento do contexto de desigualdade social e regional característicos da nossa Federação. 
A Carta de 1988, ao mesmo tempo em que conferiu autonomia aos governos subnacionais para organizarem seus próprios sistemas, inseriu um comando para que esses sistemas atuassem em regime de colaboração (art. 211, $\$ 4^{\circ}$ ). Com relação às competências, reservou à Uniāo a organização e o financiamento do sistema federal e a assistência técnica aos estados, municípios e Distrito Federal para o desenvolvimento dos seus sistemas de ensino e atendimento prioritário à escolaridade obrigatória. Para os municípios, o termo preferencialmente introduzido pelo legislador constituinte deixou margem de liberdade para a atuação. Não houve atribuição de competência específica para os estados.

Ademais, o que deveria ser entendido por regime de colaboração e como ele deveria ser estruturado não foi explícito no texto constitucional. Apesar de alguns avanços introduzidos posteriormente, ${ }^{8}$ a manutenção do modelo de sistemas subnacionais autônomos aliado à ausência de instrumentos específicos para conferir organicidade à política, dificultava a articulação dos sistemas e o estabelecimento de prioridades comuns.

Considerando que à União não foi conferida responsabilidade direta pela oferta da educação básica, seu dever para com essa etapa limitava-se ao fornecimento de assistência técnica e financeira para o "desenvolvimento dos sistemas de ensino e o atendimento prioritário à escolaridade obrigatória" (redação original do art. 211, $\$ 1^{\circ}$ da CF $),{ }^{9}$ permanecendo com um papel subsidiário na gestão da política, sem instrumentos relevantes de coordenação federativa.

Nos anos que se sucederam à promulgação da Constituição, as transferências voluntárias a cargo do governo federal eram distribuídas de maneira clientelista aos governadores e prefeitos aliados ao partido da Presidência da República à época, sem uma estratégia clara de indução (Sumiya, 2006; Segatto, 2015). Ademais, embora a CF de 1988 tenha mantido a vinculação de recursos para a educação, o fato de não ter especificado como se distribuiria essa alocação em cada nível de ensino, somado à disparidade de arrecadação entre os entes federados, conduziu a uma desigualdade entre redes intra e interestaduais (Sumiya e Franzese, 2007). Em verdade, os primeiros anos após o advento da CF de 1988 podem ser caracterizados pela dispersão de esforços e ausência de coordenação federal no processo de descentralização, com atuação frágil e irregular do Ministério da Educação (MEC), mantendo-se praticamente inalterado o quadro das desigualdades educacionais herdadas do período anterior (Abrucio, 2010; Segatto e Abrucio, 2016).

8. Como a ampliação do percentual de recursos vinculados à educação e de elementos de concepção de uma política de caráter nacional, tais como planejamento plurianual para integração de ações, monitoramento dos estudantes e algum nível de padronização de currículos (Ipea, 2009).

9. Note-se que tanto no art. 208 quanto no art. 60 do ADCT, os dispositivos constitucionais a respeito do dever do Estado com a educação dirigiam-se ao Estado e ao poder público, de forma genérica, não havendo um comando específico para a União. 
Somente a partir de 1996, foram implementadas inovaçōes institucionais na tentativa de garantir coordenação, com maior compromisso da União nesses arranjos. Como veremos, nem todas as inovaçóes experimentadas e comportamentos observados decorrem direta e imediatamente das reformas do texto constitucional, mas as emendas constitucionais são marcos importantes que delimitam, inspiram e refletem os movimentos experimentados em dois momentos distintos de coordenação federativa da educação básica brasileira.

\section{A EC № 14/1996 - ESTABELECENDO OS FUNDAMENTOS NORMATIVOS PARA A COORDENAÇÃO FEDERAL}

Em 1996, foram finalmente introduzidas no texto constitucional diretrizes para o enfrentamento das iniquidades em matéria de educação. A EC no 14/1996 determinou expressamente que a União atue "de forma a garantir equalização de oportunidades educacionais e padrão mínimo de qualidade do ensino mediante assistência técnica e financeira aos estados, ao Distrito Federal e aos municípios" (art. $211, \$ 11^{\circ}$ da CF). Além de alargar a responsabilidade da União, a EC no $14 / 1996$, substituiu, na parte das competências municipais, o ensino pré-escolar por educação infantil - que envolve também o segmento de creches destinadas ao público de 0 a 3 anos de idade - e introduziu dispositivo relativo à competência dos estados e do Distrito Federal (não contemplados explicitamente no arranjo federativo de 1988), repetindo a fórmula da atuação prioritária, dirigida, neste caso, ao ensino médio. $\mathrm{O}$ ensino fundamental apareceu enfim como competência simultânea de estados e municípios.

Ao atribuir a responsabilidade pela função redistributiva ${ }^{10}$ e supletiva em relação aos demais sistemas de forma a garantir a equalização de oportunidades educacionais e padrão mínimo de qualidade, a reforma de 1996 estava, efetivamente, incumbindo ao governo central coordenar a atuaçáo dos entes federativos em direção aos objetivos da educação nacional. Foi, assim, reforçado o comando original que falava em igualdade de condiçôes para o acesso e a permanência na escola (art. 206, I) e a garantia de padráo de qualidade (art. 206, VII), e ampliado o comando de padronizaçáo e de reduçáo das desigualdades - tanto no que diz respeito ao acesso quanto à qualidade dos serviços educacionais. A EC no 14/1996 é, pois, o grande marco desse período, viabilizando o protagonismo da União e sugerindo a estruturação da coordenação federativa.

Mas, como alerta Arretche, Vazquez e Gomes (2012), a União dispunha de limitados instrumentos de regulação e não controlava diretamente os recursos fiscais na educaçấo. Exercer esse papel coordenador e de convergência sobre sistemas autônomos

10. A Exposição de Motivos da PEC no 233/1995, que viria a se transformar na EC no 14/1996, explicitava o propósito de reforçar a responsabilidade da União pela sua função redistributiva. 
e independentes sem atuar diretamente na oferta do serviço nem deter a autoridade normativa e de financiamento se colocou como um grande desafio. Para além da distribuição de competências previstas na própria Constituição, o único instrumento constitucional de coordenação federativa previsto até então se restringia à menção a um plano nacional de educação destinado "à articulação e ao desenvolvimento do ensino em seus diversos níveis e à integração das açôes do poder público". Apesar da previsão constitucional em 1988 (art. 214 do texto original), o primeiro plano nacional de educaçâo só viria a ser promulgado em $2001 .{ }^{11}$ Ou seja, o plano não se constituiu de fato como instrumento de coordenação por ocasião da promulgação da $\mathrm{CF}$.

A reforma de 1996 introduziu, enfim, um novo mecanismo de coordenação, destinado a organizar a repartição dos recursos destinados à educação: o Fundo de Desenvolvimento e Manutenção do Ensino Fundamental e Valorização do Magistério. O Fundef vigorou por dez anos (1997-2006) no âmbito de cada estado e do Distrito Federal, sendo composto por um percentual sobre receitas estaduais e municipais. ${ }^{12} \mathrm{Além}$ de estabelecer critérios para a partilha dos recursos destinados ao ensino fundamental, havia previsão constitucional vinculando parte destes recursos aos gastos classificados como de manutenção e desenvolvimento do ensino e remuneração de docentes. A repartição por matrícula garantia maior uniformidade no volume de gastos e a subvinculação, que direcionava a alocação destes a determinados objetivos, tendiam a reduzir as desigualdades em cada estado e garantir convergência de açóes entre os governos subnacionais. Já para reduzir a desigualdade na capacidade de gastos entre os diferentes estados e regióes, estabeleceu-se que, a cada ano, a União complementaria os recursos dos fundos dos estados que não atingissem o valor mínimo de gasto por aluno. Vale notar que o Fundef foi criado no mesmo ato em que se atribuiu à União a responsabilidade de garantir a equalização de oportunidades educacionais e padrão mínimo de qualidade (EC n⿳o 14/1996) mediante assistência técnica e financeira aos estados e municípios. Entretanto, esse mecanismo complexo de fundos para repartição dos recursos alterou apenas parcialmente a posição da União em relação ao financiamento da política.

No campo infraconstitucional, o período é marcado pela promulgação de uma nova Lei de Diretrizes e Bases da Educação (LDB). ${ }^{13}$ A lei introduziu a concepçấo de educação básica e aprofundou o tema da organização da educação nacional,

11. Para um histórico da construção dos planos nacionais de educação, ver: <https://bit.ly/2zUXdQi>.

12. Sua operação se baseava na definição de um valor per capita por aluno, obtido pela divisão do total de recursos arrecadados pelo número de vagas ofertadas no ensino fundamental em todo o estado, sendo repassado de acordo com o número de alunos matriculados em cada uma das redes (estadual e municipais).

13. A primeira LDB após a redemocratização, a Lei no 9.394/1996 também é a terceira lei de diretrizes e bases da educaçãa do Brasil. Apesar de prevista desde a Constituição Federal de 1943, a primeira LDB foi promulgada somente em 1961, após treze anos de debates e tramitação. A versão de 1971 foi elaborada na vigência do regime militar e refletiu o projeto autoritário e centralizador do período. 0 projeto da atual LDB começou a ser debatido ainda no período da constituinte, mas só viria a ser aprovada cerca de uma década após, três meses depois da EC oㅡ 14/1996. As tramitações longas e recheadas de embates revelam as tensões em torno da educação nacional. 
estabelecendo incumbências para União, estados, municípios, estabelecimentos de ensino e docentes, reafirmando o regime de colaboração e assegurando aos sistemas de ensino liberdade de organizaçáo. O texto da lei é mais contundente que o da CF de 1988 ao atribuir à União - neste caso expressamente - a coordenação da política nacional de educação. Além disso, a LDB dá substância ao conceito de equalização de oportunidades mencionado na EC no $14 / 1996$ ao determinar que a União, em colaboração com os estados, o Distrito Federal e os municípios, estabeleça padrão minimo de oportunidades educacionais para o ensino fundamental, baseado no cálculo do custo mínimo por aluno, capaz de assegurar ensino de qualidade, direcionando a ação supletiva e redistributiva à correção de disparidades de acesso e qualidade de ensino (arts. 74 e 75). Se a LDB não chegou a racionalizar a açáo conjunta dos entes federativos nem avançar na construção de um sistema orgânico ou de estruturas para concertaçáo de açóes, ${ }^{14}$ ela teve o mérito de definir melhor as responsabilidades de cada ente e explicitar o papel da União na coordenação da política, com ênfase no padrão mínimo de oportunidades educacionais baseado no custo aluno-qualidade (art. 4º IX). Esse instrumento, entretanto, foi e continua sendo objeto de intensos embates entre gestores e a comunidade educacional, não tendo sido implantado até hoje. ${ }^{15}$

A LDB de 1996 também reforçou a importância do planejamento coordenado e articulado da educação nacional quando finalmente fixou o prazo de um ano para que a Uniáo elaborasse, em colaboração com os estados, o Distrito Federal e os municípios, o Plano Nacional de Educação, com diretrizes e metas para os dez anos seguintes (art. 87, $\$ 1 \stackrel{\circ}{\circ}$, capítulo das disposiçóes transitórias). O PNE enfim publicado em 2001 (Lei no 10.172/2001) consistiu em um extenso documento (81 páginas) com rico diagnóstico sobre a educação, as diretrizes, os objetivos e as metas detalhadas para cada nível e modalidade de ensino. A crítica que se fez ao documento, porém, é que suas metas não levaram em conta o ritmo das melhorias educacionais que o antecederam, nem relacionaram as açóes que seriam implementadas para o alcance delas. ${ }^{16}$ Tampouco garantiriam as fontes de recurso para tanto. Dourado (2010) revela que:

o PNE, apesar de apresentar metas de amplo alcance, indicando grandes desafios para a melhoria da educação nacional, configurou-se como plano formal, marcado pela ausência de mecanismos concretos de financiamento. Outro aspecto a ser realçado

\footnotetext{
14. Cruz (2011) inclusive aponta que a divisão de responsabilidades pelos serviços educacionais entre os entes federados na LDB cristaliza a ausência de um sistema nacional efetivamente articulado e orgânico.

15. Em 5 de maio de 2010, o Conselho Nacional de Educação, acatando projeto concebido no seio das entidades educacionais, emitiu parecer favorável à adoção do CAQi (custo aluno-qualidade inicial, ou seja, o valor suficiente para estabelecimento de um padrão mínimo de qualidade). Passados mais de dez anos, o parecer, entretanto, não foi até hoje homologado pelo ministro da Educação, condição necessária à sua validade. 0 CAQ/CAQi foi previsto no atual PNE com prazo até 2016 para ser implementado pelo MEC.

16. Para o ensino médio, por exemplo, o PNE apontava como objetivo melhorar o aproveitamento dos alunos e reduzir a repetência e a evasão, mas até 2009 nenhum dos programas de apoio do MEC (merenda, transporte, livro didático) contemplava o ensino médio.
} 
refere-se à dinâmica global de planejamento adotada, em que não se efetivou a organicidade orçamentária para dar concretude às metas do PNE, na medida em que o Plano não foi levado em conta no processo de elaboraçáo do Plano Plurianual (PPA) e de suas revisóes. Esse cenário é revelador de um dos seus grandes limites estruturais (p. 684-685).

O projeto aprovado pelo Congresso Nacional continha metas relacionadas ao financiamento, prevendo a elevação do percentual aplicado em educação. $\mathrm{O}$ ex-presidente Fernando Henrique Cardoso, todavia, vetou nove pontos do PNE referentes a repasses de recursos, inclusive o dispositivo que vinculava $7 \%$ do produto interno bruto (PIB) para educação. Saviani (2007) acusa a mutilação do PNE pela Presidência da República exatamente sobre seus pontos mais nevrálgicos, esvaziando por completo o plano. O esforço de fornecer um conjunto de diretrizes e metas capazes de orientar e balizar a política educacional do país foi neutralizado pelo escoamento das verbas correspondentes. Assim, o potencial organizador e condutor do PNE 2001-2011 como instrumento capaz de promover a coordenaçáo da política não se revelou na prática.

No que tange à gestão dos programas e das ações para o ensino fundamental sob responsabilidade do governo federal, esse período foi marcado pela adoção de critérios universalistas, objetivos e mais transparentes para as transferências voluntárias (em contraposição às práticas clientelísticas do período anterior); por uma focalização das iniciativas destinadas às localidades com concentração de pobreza e por uma forte tendência de descentralização da gestão dos principais programas pela transferência de recursos aos governos subnacionais e, em alguns casos, às próprias unidades escolares (Ipea, 2009). Consideramos que a formulação de critérios racionais de alocação inaugura um padrão de ação normatizadora da União, sob responsabilidade do MEC e do Fundo Nacional de Desenvolvimento da Educação (FNDE), ${ }^{17}$ com instrumentos de indução por adesão.

Houve avanços também no Sistema de Avaliação da Educação Básica (Saeb) e no Censo Escolar, importantes para o controle das transferências do FUNDEF (Segatto e Abrucio, 2016). Aliás, a introdução de avaliaçóes em larga escala pelo Instituto Nacional de Estudos e Pesquisas Educacionais Anísio Teixeira (INEP) representou um grande avanço, favorecendo a elaboração de análises mais consistentes sobre a situação da educação nacional e favorecendo o planejamento da política. Porém, o caráter amostral dos levantamentos impedia a realização de diagnósticos específicos sobre o estágio de desenvolvimento de cada rede, inviabilizando a identificação das necessidades para fins de direcionamento da atuação mais efetiva da função supletiva da União. Ademais, de acordo com estudo realizado por Cruz (2011),

17. O FNDE, criado em 1968, representa ao mesmo tempo um fundo especial e uma autarquia federal, vinculado ao Ministério da Educação e tem como objetivo executar ações de apoio à educação básica e prestar auxílio financeiro e técnico aos governos subnacionais, financiadas, em sua maioria pela cota federal do salário-educação. 
a maior parte dos recursos administrados pelo FNDE, nesse período (1995-2006), destinava-se às açóes de transferência direta ou automática, ou seja, aquelas com critérios objetivamente definidos. Já a assistência financeira voluntária - aquela com maior poder de indução, porque com maior grau de discricionariedade da União para decidir sobre critérios de alocação - ficou com a menor fatia. Conforme pontua Farenzena (2011), o potencial indutor dessa estratégia depende diretamente da magnitude dos recursos disponíveis para assistência. A política restritiva de gastos sociais do governo federal, até então, fez com que a Uniáo, a despeito do esforço de criação de critérios objetivos de distribuição de recursos, exercesse sua função supletiva e redistributiva de forma ainda incipiente (Cruz, 2011).

Tendo em vista as limitações do PNE e das transferências voluntárias em se constituir como mecanismos de coordenação e indução efetivos, o Fundef restou isolado como aposta para alcançar os objetivos nacionais de universalização do ensino fundamental e redução de assimetrias até meados dos anos 2000 (Arretche, 2004; 2012)..$^{18}$ Com relação à universalização, o Fundef teve resultados quantitativos relevantes, expandindo e descentralizando as matrículas com crescimento das redes municipais e contribuindo para a universalização do ensino fundamental, que atingiu o percentual de $94,8 \%$ de escolarização líquida em 2006. Todavia no que diz respeito ao efeito equalizador, bem como a instituição de um padrão de qualidade, deixou a desejar.

A participação da União no Fundef se observa, portanto, em duas ordens distintas. Na primeira, uma participação ativa ao elaborar e propor a PEC que lhe deu origem, concebendo mecanismos e critérios para redistribuição dos recursos no interior dos sistemas de ensino, com vistas à redução das assimetrias intraestaduais, guardando, para si mesma, no entanto, uma posição periférica no arranjo. $\mathrm{Na}$ segunda ordem, a União teve participação subsidiária ao aportar recursos próprios para garantir a equidade de gastos e reduzir as desigualdades entre sistemas. Como já apontamos, a atribuição expressa da sua responsabilidade pela coordenação da política educacional na LDB ocorreu simultaneamente à criação do Fundef - a Emenda Constitucional no 14/1996 - o que nos permite afirmar que se apostou nesse mecanismo de repartição como instrumento fundamental para trazer organicidade à política de educação e garantir o padrão de qualidade e equalização preconizado pela Constituição.

Apesar disso, o contexto de ajuste fiscal federal em que nasceu o Fundef limitou a utilização desse mecanismo como instrumento de ação redistributiva. Franzese (2010) apurou que apenas oito estados foram beneficiados com a complementação

18. Arretche (2004) afirma que o Fundef continha em si diversos elementos que o tornavam um instrumento institucional poderoso de coordenação, capaz de estimular a adesão e reduzir assimetrias: instrumento insculpido na Constituição Federal (Emenda Constitucional no 14, de setembro de 1996); elimina incertezas ao tornar as transferências intraestaduais previsíveis e asseguradas constitucionalmente, reduz escolhas dos governos subnacionais quanto à aplicação dos recursos e estabelece um vínculo direto entre encargos e receitas (montante de recursos vinculados às matrículas). 
federal no seu primeiro ano de funcionamento; quatro receberam recursos federais em 2003 e apenas dois receberam complementação federal em 2006. Cruz (2011) acusa o governo federal de descumprir a própria lei ao não definir o valor/aluno da maneira concebida, deixando de aportar os recursos prometidos aos fundos, o que reduziu o impacto equalizador do fundo. ${ }^{19}$ Oliveira e Sousa (2010) falam de "desembarque" do financiamento do ensino fundamental por parte do governo federal. Assim, consideramos que a resistência da União em exercer plenamente seu papel, contribuiu para esse resultado incompleto.

Como observado, esse envolvimento parcial da União na sua função de coordenação, em especial sob a perspectiva financeira, se repetiu não só no Fundef, mas também no PNE e nas transferências a cargo do FNDE. A postura do governo federal nesse período foi, portanto, contraditória e hesitante: concebeu instrumentos de coordenação, mas não contribuiu na medida necessária para que funcionassem efetivamente; formulou mecanismos de equalização e elevação da qualidade, mas não alocou recursos substantivos para tal finalidade. Nessa linha, Cruz (2011) indica que o período de 1995 a 2006 foi marcado pela desresponsabilização da Uniáo com o financiamento da educaçáo, no bojo de um processo mais amplo de ajuste econômico e diminuição do papel do Estado que incluiu "o fechamento de órgãos federais, a transferência de responsabilidade de oferta de serviços sociais para os demais entes federados, a diminuição dos investimentos federais em políticas sociais, as privatizaçóes e a terceirização e desestatização de serviços" (Cruz, 2011, p. 82).

Em suma, se a partir de 1996 se verificou a maior participação da União em relaçáo ao período anterior, ela se revelou mais no papel regulatório. Os instrumentos constitucionais e infraconstitucionais mobilizados no período revelam que o governo federal se preocupou em dar corpo a diversos aspectos de coordenação da política de educação, nas áreas de planejamento, avaliação e repartição de recursos, sem, no entanto, fornecer - ela própria - aportes financeiros significativos.

\section{AS ECS №s 53/2006 E 59/2009 - AMPLIANDO $O$ ESPAÇO DE COORDENAÇÃO DA UNIÃO}

A partir da segunda metade dos anos 2000, a trajetória dos instrumentos de coordenação e arranjos institucionais indica uma mudança nas relaçóes intergovernamentais na educação com a criação do Fundeb (que viria a substituir o Fundef), a extensão progressiva do ensino obrigatório, o lançamento do Plano de Desenvolvimento

19. Cunha et al. (2016) apontam que durante a vigência do Fundef os ministérios da área econômica mantiveram controle rigoroso sobre o caixa da União, resultando em um volume cada vez menor de recursos federais destinados à complementação, de forma que os volumes dos aportes de recursos federais ao fundo deram-se de forma decrescente. No último ano do programa, segundo os autores, este correspondia a apenas $63 \%$ do valor legal, calculado segundo a fórmula estabelecida na regulamentação do fundo (art. 6\%, da Lei no 9.424/1996). Vale lembrar que a complementação da União visava, exatamente, à redução da desigualdade na capacidade de gastos entre os diferentes estados e regiỗes. 
da Educação (PDE) e do Plano de Ações Articuladas (PAR). Este foi um período bastante fértil na construçáo de novos arranjos e instrumentos de coordenação sob o comando do governo central.

O primeiro grande marco desse período é a Emenda Constitucional no 53 , de 19 de dezembro de 2006, que criou o Fundo de Manutenção e Desenvolvimento da Educação Básica e de Valorização dos Profissionais da Educação (Fundeb) em substituição ao Fundef, alterando novamente o art. 60 dos ADCT. A emenda trouxe ainda a introdução da noção de educação básica no texto constitucional (art. 221, $\$ 5^{\circ}$ ), o reforço ao piso salarial profissional nacional para os profissionais da educação escolar pública, (art. 206, VIII) ${ }^{20}$ o critério para distribuição do salário-educação com base nas matrículas dos alunos (art. 211, $\$ 6^{\circ}$ ) e a caracterização da educação infantil (atendimento às crianças de $0 \mathrm{a} 5$ anos em suas duas fases: creche e pré-escola) (art. 208, IV).

O modelo essencial do Fundef foi mantido no Fundeb: um fundo contábil instituído no âmbito de cada estado e do Distrito Federal, com previsão de repartição dos recursos de forma proporcional às matrículas. Mas, com essa emenda, a educação infantil e o ensino médio ganharam também representatividade, ampliando-se o financiamento para toda a educação básica, incluindo a educação especial e a educação de jovens e adultos, o que provocou um aumento de mais de 50\% no número de estudantes atendidos pelo fundo. ${ }^{21}$ Para tanto, o Fundeb aumentou o percentual de $15 \%$ para $20 \%$ das fontes de arrecadação destinadas a ele, além de estabelecer um percentual fixo para a parcela de contribuição da União. O Fundeb age, assim como o Fundef, não apenas como instrumento distributivo, mas também como elemento de normatização do gasto, ao definir que os respectivos recursos sejam aplicados exclusivamente nos âmbitos de atuação prioritária de cada ente, com pelo menos $60 \%$ destinado ao pagamento dos profissionais do magistério da educação básica em efetivo exercício.

O aporte da União ao Fundeb, com a nova regra, passa a ser fixo e assegurado, e não mais variável em função de um mínimo nacional. Essa nova estratégia aumentou significativamente o fluxo de recursos do governo federal aos fundos, passando de $\mathrm{R} \$ 400$ milhóes para o Fundef, em 2006, para $\mathrm{R} \$ 4,8$ bilhōes já no Fundeb em 2008, e atingindo R \$9, 1 bilhóes, em 2010, segundo o FNDE (Cunha et al., 2016, p. 378). De acordo com Pinto (2014), o Fundeb teve um impacto significativo na redução das disparidades inter-regionais, devido particularmente à ampliação do complemento financeiro da União. ${ }^{22}$

20. A referência ao piso nacional já se encontrava no texto original da CF/1988 e foi mantida pelas reformas posteriores, mas é a EC no 53/2006 quem o insere em inciso destacado e introduz prazo para a promulgação de lei federal, reforçando a responsabilidade da União na política de valorização docente (ADCT art. 60, II, e).

21. Documento divulgado pela assessoria de comunicação do MEC por ocasião do lançamento do Fundeb projetava que o número de estudantes passaria de 30,2 milhões para 48,1 milhões a partir do quarto ano de vigência do fundo, baseando-se nos dados do Censo Escolar de 2005. Disponível em: < https://bit.ly/2leCzCu>.

22. Ainda segundo esse autor, após a implementação completa do Fundeb, dez dos 26 estados receberam complementação da União sendo que, em alguns deles, os recursos adicionais representaram um acréscimo igual ou superior a $50 \%$ do valor inicial (Pinto, 2014, p. 11). 
Além de estabelecer um patamar mínimo para a complementação da União, a medida proibia a utilização do salário-educação nessa complementação. Assim, a participação total do governo federal na educação básica aumentou significativamente no período, tanto pela complementação da União ao Fundeb quanto por meio de programas federais, ${ }^{23}$ de forma que a razão do investimento público direto por estudante da educação superior sobre a educação básica caiu de 11,1, em 2000, para 5,1, em 2009 (Brasil, 2011).

Em 2009, uma nova Emenda Constitucional foi aprovada. A EC no 59 trouxe três principais inovaçóes: i) estendeu o ensino obrigatório e gratuito, na forma da educação básica, dos 4 aos 17 anos de idade (art. 208, I); ii) introduziu expressamente o termo "sistema nacional de educação" a ser articulado pelo Plano Nacional de Educação (art. 214) mediante regime de colaboração entre os entes federativos; e iii) excluiu a educação dos efeitos da Desvinculação das Receitas da União (DRU) (art. 76, $\$ 3^{\circ}$, ADCT), ampliando simultaneamente o compromisso do poder público com a universalização da educação e a destinação de recursos federais para essa finalidade. ${ }^{24}$

Por sua vez, a expansão da obrigatoriedade do ensino em 2009 também pesou sobre os provedores diretos do serviço: os estados e - mais ainda - os municípios. Se a rede estadual já dispunha, em grande medida, de capacidade instalada para absorver a obrigatoriedade do ensino médio, no caso dos municípios, a ampliação da obrigatoriedade para a educação infantil enfrentava desafios maiores: a necessidade de criação de vagas em estabelecimentos de educação infantil para absorção de um significativo contingente de crianças menores de 6 anos que ainda não integravam o sistema de ensino. ${ }^{25}$ Dados da PNAD-2007 revelavam que 30\% das crianças de 4 a 5 anos ainda estavam fora da escola.

Em que pese os desafios colocados, o fato é que essas duas emendas constitucionais editadas a partir de 2006 ampliaram o direito à educação e, consequentemente, a obrigação do poder público com a provisão do serviço. Passou-se do compromisso com a universalização de uma etapa - o ensino fundamental - para o compromisso com a universalização de toda a educação básica (pré-escola, fundamental e médio, além de educação de jovens e adultos, educação especial, indígena e quilombola). A tarefa pesava inicialmente sobre estados e municípios, enquanto provedores do serviço, mas também pendia sobre a União, responsável

23. Nos termos do art. 212, §5, da Constituição, a contribuição social do salário-educação constitui fonte adicional para financiamento da educação básica pública, devendo ser aplicada na manutenção e no desenvolvimento do ensino (MDE). No caso da União, sua parcela deve servir para financiar programas e projetos voltados para a educação básica, de forma a propiciar a redução dos desníveis socioeducacionais entre os municípios, estados e regiões brasileiras em respeito à sua função supletiva e redistributiva.

24. Cunha et al. (2016) apontam que o retorno dos recursos da DRU permitiria repor ao orçamento do MEC, de acordo com o ministro Fernando Haddad, recursos da ordem de $R \$ 7,5$ bilhões por ano.

25. A obrigatoriedade do ensino cria simultaneamente dois deveres: de um lado, a garantia e a responsabilidade da família pela matrícula e frequência das crianças e jovens na escola; de outro, o dever do Estado de ofertar o serviço. Torna-se, pois, um direito oponível ao Estado, que pode ser compelido a oferecer vagas para todos que assim demandarem. 
pelo apoio técnico e financeiro, pela equalização de oportunidades educacionais, padrão de qualidade e pela coordenação da política.

Para fazer frente a todos esses desafios, além dos novos instrumentos introduzidos pelas reformas constitucionais, houve um reposicionamento do governo federal, consubstanciado nos instrumentos de coordenação mobilizados no plano infraconstitucional. Nesse sentido, em abril de 2007, foi lançado pelo MEC o Plano de Desenvolvimento da Educação (PDE) o qual é descrito como um instrumento estrutural de longo prazo, que concretiza uma visão estratégica da educaçáo e revela o compromisso do poder público com todo o ciclo de ensino, pressupondo articulação e coordenação da educação nacional (Brasil, 2007). O PDE trouxe consigo, além de programas e açôes variadas, instrumentos de coordenação inovadores que ampliam a ação da União na educação básica, seja por meio da profusão de mecanismos de incentivos e transferências condicionadas, seja por meio de instrumentos não financeiros de coordenação.

Há que se lembrar que o PNE de 2001 estava em andamento quando o governo Lula lançou o PDE. Por que lançar um novo plano com outro em andamento? A explicação dada à época foi que o PDE não substituía ou se contrapunha ao PNE, ao contrário, se configurava como "um plano executivo para o PNE" ou " $a$ tradução instrumental do PNE/2001” (Brasil, 2007, grifo nosso). Os programas enfeixados no PDE consistiam em diversas açóes do governo federal destinadas à melhoria da educação básica em direção às metas definidas no PNE de 2001. Todavia, para além de um mero pacote de medidas de assistência técnica e financeira, o PDE era uma tentativa de imprimir visão sistêmica à educação, ${ }^{26}$ contando com um conjunto de programas e açóes voltados a todos os níveis e modalidades de ensino, englobando estratégias e ações de natureza diversa e articuladas em um sistema de incentivos - financeiros e não financeiros - destinados a estimular a adesão de estados e municípios às açóes prioritárias e metas de desenvolvimento da educação definidas pelo governo federal. O que recebeu o nome de Plano de Desenvolvimento da Educação foi, portanto, um conjunto de medidas que viria a nortear toda a atuação do Ministério da Educação a partir de entấo, dentre as quais podem ser destacados os seguintes instrumentos de coordenação:

- Plano de Metas Compromisso Todos pela Educação;

- Plano de Açóes Articuladas (PAR);

- Programas do FNDE; e

- Índice de Desenvolvimento da Educação Básica (Ideb).

26. Segundo Corbucci e outros (Ipea, 2009), o PDE reconhece as conexões entre educação básica, educação superior, educação profissional e alfabetização de jovens e adultos e busca potencializar políticas com base nestes níveis educacionais, de forma a reforçá-los reciprocamente e dar consequência à articulação da educação com o desenvolvimento socioeconômico que se realiza no território. 
O Plano de Metas Compromisso Todos Pela Educação (Decreto ํo 6.094/2007, arts. $1^{\circ}$ e $2^{\circ}$ ) configura documento com 28 diretrizes para melhoria da qualidade da educação básica, concebido pelo $\mathrm{MEC},{ }^{27}$ para adesão de estados e municípios. Trata-se de um protocolo de intençóes, indicando objetivos a serem perseguidos pelos gestores dos sistemas de ensino, tais como: estabelecer como foco a aprendizagem; combater a repetência e a evasão escolar; valorizar a formaçâo ética, artística e a educação física; promover a educação infantil ou transformar a escola num espaço comunitário. O propósito do Compromisso, portanto, não era o de vincular os gestores a açóes específicas pré-determinadas, mas o de se estabelecer como estratégia de mobilização e de convergência de esforços dos três níveis de governo (União, estados, municípios) para o alcance de objetivos prioritários da política de educação. Camini (2010) o descreve como "eixo articulador estratégico de descentralização do PDE". Para garantir uma adesão massiva e atrair estados e municípios, o MEC acenava com a promessa de priorização de atendimento em seus programas de assistência voluntária àqueles que aderissem ao Compromisso e cumprissem as demais etapas. A estratégia de mobilização incluiu ainda uma "caravana da educação", em que os principais gestores do MEC percorreram todas as regiōes brasileiras para a celebração do pacto. $\mathrm{O}$ resultado do esforço garantiu que, um ano após seu lançamento, os 26 estados e o Distrito Federal e 98\% dos municípios tivessem aderido ao Compromisso que, além das prioridades comuns, estabelecia metas de qualidade específicas a serem alcançadas por cada ente subnacional, como aprofundaremos adiante.

Se o Compromisso foi o instrumento programático de mobilização e convergência de esforços, o PAR representou o eixo operacional e de articulação federativa do PDE. A adesão às diretrizes e metas estabelecidas no Compromisso implicava assunção de uma série de responsabilidades pelos aderentes, as quais, para serem cumpridas, dependiam em grande parte do apoio suplementar e voluntário da Uniâo às redes públicas de educação básica municipal e estadual. A distribuição dessas responsabilidades se concretizava na elaboração do PAR, que agregou duas ferramentas: uma de diagnóstico, outra de planejamento. Como ponto de partida, o PAR induz os estados e municípios aderentes a realizar um levantamento dos aspectos demográficos (como população, PIB e Índice de Desenvolvimento Humano - IDH) e educacionais locais (como taxa de analfabetismo, equipe escolar, situação das escolas), e a partir do cruzamento e da sistematização desses dados, elaborar um quadro da situação da educação local com respeito a quatro dimensóes: gestâo educacional, formação de professores e profissionais da educação, infraestrutura física e recursos pedagógicos. Na segunda etapa do instrumento, parte-se

27. O PDE recebeu críticas pela ausência de participação da sociedade, mas as diretrizes elencadas no compromisso são resultado dos debates públicos que vinham ocorrendo em diversos fóruns da área. Sobre isso, ver Haddad, Carvalho e Saraiva (2008). 
dos indicadores relacionados no diagnóstico para identificar as açóes prioritárias, estratégias e forma de execução que integram um plano de ação. ${ }^{28}$ Este plano é, então, traduzido em um termo, a ser firmado pelo ministro da Educação e pelo prefeito ou governador, liberando o apoio técnico e financeiro do MEC aos estados e municípios por intermédio dos programas de apoio às redes escolares executados pelo FNDE.

Em 2007, ano de lançamento do PDE, foram elaborados os PAR de 1.242 municípios considerados prioritários por terem os piores índices de qualidade (Brasil, 2007) e até 2011 todos os estados e mais de 5.500 municípios tiveram seus PAR concluídos. Para cada um deles, gerou-se um termo de cooperação, no qual foram detalhadas as ações que passariam a contar com o apoio técnico e/ou financeiro do Ministério da Educação, consubstanciando o compromisso da União com cada um dos entes federativos. O texto inserido no formulário padronizado preenchido pelos estados e municípios, posteriormente submetido ao MEC para análise e aprovação, assim define os compromissos assumidos.

No momento da assinatura do Termo de Adesáo ao Plano de Metas Compromisso Todos pela Educação, assumimos o compromisso de melhorar nossos indicadores educacionais a partir do desenvolvimento de açôes que possibilitem o cumprimento das diretrizes estabelecidas no referido Termo de Adesão e também o alcance das metas estabelecidas para o Ideb (Brasil, 2007a, p. 3).

Essa lógica de reciprocidade constitui a principal inovação do PAR enquanto instrumento de coordenação federativa: de um lado, a organizaçáo da ação dos gestores locais a partir do diagnóstico de suas necessidades e de diretrizes para desenvolvimentos de suas redes, gerando um planejamento plurianual e sistêmico; de outro, a organização do apoio da Uniáo aos estados e municípios, transformando um sistema aleatório de adesão por convênios esparsos e fragmentados em um sistema coordenado de incentivos, direcionado para o alcance de metas previamente pactuadas e com responsabilidades pré-definidas. ${ }^{29} \mathrm{O}$ PAR proporciona, portanto, o estabelecimento de açóes coordenadas entre os níveis de governo central e local, a partir da definição de objetivos comuns, ou, nas palavras de um alto dirigente do MEC (entrevista 57) "organizar a demanda e qualificar a oferta da ação supletiva do MEC".

28. A elaboração do diagnóstico envolvia equipes técnicas locais, membros do comitê local de acompanhamento do PAR e técnicos ou consultores do MEC. Parte das informações era fornecida pelo próprio MEC/Inep, outra parte era coletada em trabalho de campo. Os indicadores eram construídos a partir das informações coletadas e inseridos no Sistema Integrado de Monitoramento, Execução e Controle (Simec), recebendo uma pontuação correspondente a seu grau de desenvolvimento. Com foco na melhoria dos indicadores, ações padronizadas e pré-determinadas eram sugeridas para cada indicador, de acordo com a pontuação obtida. Para um quadro completo das etapas de elaboração do PAR, ver Grin (2016, p. 233).

29. Grin (2016) informa que antes do início do PAR apenas um terço dos municípios brasileiros tinham elaborado seus planos de educação. No período pós-PAR, em 2009, esse número subiu para mais da metade e, em 2011, ele atingiu quase dois terços. 
Os programas do FNDE relacionados nos termos derivados do PAR se enquadram como assistência financeira voluntária no âmbito da função supletiva da União. É certo que o apoio às redes de educação básica estaduais e municipais não se inaugura com o PDE; entretanto, este imprimiu uma necessidade de formulação de novos programas e redesenho dos antigos, para que fosse oferecido um bloco de ofertas modeladas especialmente para auxiliar os estados e municípios a cumprir cada uma das ações identificadas no PAR.$^{30} \mathrm{~A}$ inovação, pois, se revelou na vinculação desses programas aos instrumentos que os antecedem - o Compromisso e o PAR permitindo um direcionamento do apoio federal às açóes previamente selecionadas como relevantes ao atingimento dos objetivos nacionais. Esse apoio se dá, em sua maioria, pelas transferências voluntárias de caráter discricionário e normalmente dependentes da celebraçáo de convênios, regulamentadas por portarias ministeriais e/ou instruçóes normativas, sobre as quais o MEC e FNDE gozam de autonomia para definir as regras e os critérios de atendimento, concentrando um alto poder regulatório nas mãos do governo federal. Aliado a uma larga expansão do volume de recursos à disposição do FNDE, ${ }^{31}$ isso permitiu que os programas por adesão funcionassem como mecanismo de indução de políticas de caráter nacional e se constituíssem como instrumento de coordenação.

O PAR - entendido de forma ampla como ferramenta de diagnóstico, planejamento e organização da ação supletiva da União - é, portanto, o mais importante instrumento de coordenação federativa do período, considerado por alguns autores, como a própria consubstanciação do regime de colaboração, porque traduz a parceria e a sintonia entre a União e os governos subnacionais em torno de diretrizes, estratégias e açóes (Terto, Castro e Sano, 2017; Fernandes, 2010; Farenzena, 2011; Grin, 2016). Como instrumento operacional do PDE, o PAR se tornou o substrato da relação do governo federal com os governos locais e viabilizou o acesso direto aos programas do FNDE, sem a necessidade de consultores externos ou lobistas, ampliando a base de incidência da assistência supletiva da União. Grin (2016, p. 231) informa que, antes de 2007, grande parte dos municípios menores e com mais graves carências educacionais ( $80 \%$ deles no Norte e Nordeste) nunca haviam recebido recursos de transferência da União.

Vale dizer que parte desses autores (Terto, Castro e Sano, 2017; Grin, 2016) também critica o modelo de implementação do PAR, argumentando que seu caráter hierárquico, com soluçóes prontas e padronizadas formuladas unilateralmente pela

30. De acordo com o MEC (Brasil, 2007), o PDE englobava mais de quarenta programas voltados a todas as etapas e modalidades da educação, inclusive superior e profissional, envolvendo desde a oferta de material didático e tecnologias educacionais, à formação de professores e gestores, além de instalação de laboratórios de informática, banda larga para as escolas, ferramentas de planejamento e gestão para escolas e secretarias.

31. 0 orçamento do FNDE mais que triplica em apenas cinco anos, passando de cerca de R\$10 bilhões em 2006 para mais de R\$ 30 bilhões em 2011 (Brasil, 2016). Vale registrar que o orçamento do FNDE inclui os recursos federais destinados ao Fundeb. 
União, terminou por reduzir os espaços de participação dos entes na construção de soluçóes mais aderentes às suas realidades. Camini (2010) relativiza essa visão, apontando que o PDE revela a existência de um trabalho colaborativo entre as instâncias governamentais, ainda que os estados e municípios não tenham ocupado papel de protagonistas e seu envolvimento tenha sido induzido ou consentido. A autora considera que o PDE contém tanto elementos inspirados por concepçóes e práticas essencialmente democráticas (previsão de conselhos e fortalecimento e qualificação dos gestores locais) quanto ferramentas de gestão e instrumentos de inspiração gerencialista (racionalizaçâo administrativa, avaliação estandardizada, planos e processos padronizados), o que poderia explicar sua natureza contraditória.

O quarto instrumento mobilizado pelo PDE foi o Ideb, um indicador que combina a proficiência alcançada pelos estudantes em avaliaçóes externas de larga escala (Prova Brasil e Sistema de Avaliação da Educação Básica - Saeb) com a taxa de aprovaçáo escolar. No âmbito do Compromisso Plano de Metas, cada estado e cada município elaborou o próprio PAR na perspectiva de evolução positiva do Ideb, eleito, assim, como principal indicador para aferir a qualidade da educação.

Para a construção do Ideb, o Ministério da Educação teve de aprimorar seu sistema de avaliação (Saeb) e de coleta de dados (Educacenso), ampliando-os para abranger um número cada vez maior de estudantes e abandonar seu caráter amostral. Com isso, permitiu-se o diagnóstico e estabelecimento de metas por redes e por escolas e, consequentemente, refinar o direcionamento da ação supletiva da Uniáo. Permitiu-se, ainda, a utilização deste instrumento para identificação das desigualdades e dos avanços, de forma a possibilitar uma atuação em prol da redução das assimetrias.

Assim, a evolução da avaliação pelo Ideb trouxe uma dupla inovação: de um lado, a construção de um instrumento mais preciso e uniforme destinado a enxergar os diversos cenários da educação básica - desde o nível macro (nacional) até o nível micro (de cada escola) - que permitiu traçar planos de desenvolvimento individualizados; de outro, permitiu o estabelecimento de metas relativas à qualidade da educação e não apenas referentes à extensão da cobertura ou ao atendimento. Entretanto, o aspecto mais significativo do Ideb foi a possibilidade de implantação de um sistema de metas de desenvolvimento educacional para cada escola, município, estado e para o nível nacional, definindo, inclusive, metas intermediárias para cada biênio a fim de permitir o monitoramento por toda a sociedade.

Essas metas, por sua vez, desdobram-se de maneira diferente para os anos iniciais e finais do ensino fundamental e para o ensino médio, permitindo não só revelar o ponto de partida de cada um e as diferentes distâncias que os separam do ponto de chegada, mas também cada um dos percursos necessários. O propósito de estabelecer um sistema de metas - para o país, para cada rede e para cada escola — vinculava-se à ideia de obter um comprometimento dos estados e municípios com a melhoria da qualidade da educação pública (Fernandes e Gremaud, 2009), daí porque a meta 
individualizada de cada ente federativo foi indicada no termo do Compromisso firmado pelo chefe do executivo local, ${ }^{32}$ constituindo, assim, elemento indutor para a atuação dos gestores em direção à melhoria da educação básica. Ainda segundo os autores, ao projetar as trajetórias esperadas para o Ideb de cada rede de ensino, buscou-se contribuir para a redução das desigualdades regionais de qualidade educacional, esperando-se um processo de convergência dos indicadores no longo prazo.

A divulgação de indicadores de qualidade e suas metas, por sua vez, atraiu para o governo federal uma maior responsabilidade, já que revelou as iniquidades educacionais e consequentemente o tamanho do desafio de promover a equalizaçáo das oportunidades educacionais. Ao tornar transparente a radiografia da educação e apontar as trajetórias de melhoria, permite-se que a sociedade ao mesmo tempo conheça os problemas e cobre a soluçáo dos governantes. Com esse movimento, o governo federal atraiu para si um risco, já que se comprometeu perante a sociedade a alcançar os resultados que ele mesmo traçou, capitaneando um processo de melhoria da oferta de serviços cuja atribuição original não lhe pertencia diretamente. A estratégia do governo federal para dar conta desse desafio foi reforçar sua atuação supletiva e redistributiva, por meio do seu papel coordenador, apostando no planejamento e induzindo açôes de melhoria da qualidade. O PAR se insere justamente nesse contexto: ao estimular que os governos locais se comprometessem com o esforço de melhoria coordenada, a Uniáo ofereceu em troca seu compromisso de apoiá-los com açôes e recursos, moldando um novo arranjo de colaboraçáo.

Como procuramos demonstrar, os quatro principais instrumentos de coordenação do PDE para a educação básica - Compromisso de Metas, PAR, Programas do FNDE e Ideb - estáo intrinsecamente articulados, formando uma estrutura robusta de incentivos (Arretche, 2004). Aliado a um substancial aporte de recursos essa estrutura, em contraste com a anterior, colocou de vez a Uniáo no centro da arena, coordenando e calibrando os instrumentos, o que, a nosso ver, demonstrou um reposicionamento do governo federal na política de educaçáo básica. A seguir, trecho do documento de lançamento do PDE explicita essa revisão de postura (Brasil, 2007, p. 11).

Nesse sentido, a concretização do mandamento constitucional segundo o qual a União deve exercer 'em matéria educacional, função redistributiva e supletiva, de forma a garantir equalização de oportunidades educacionais e padrão mínimo de qualidade do ensino mediante assistência técnica e financeira aos estados, ao Distrito Federal e aos municípios', implicou revisão da postura da União, que a partir do PDE assumiu maiores compromissos - inclusive financeiros - e colocou à disposiçāo dos estados, do Distrito Federal e dos municípios instrumentos eficazes de avaliação e de implementação de políticas de melhoria da qualidade da educação, sobretudo da educaşão básica pública (grifo nosso).

32. 0 art. 50 do Decreto ํ 6.094, de 24 de abril de 2007 (que institui o Compromisso todos pela Educação, o Ideb e 0 PAR) diz que a adesão ao Compromisso implica a assunção da responsabilidade de promover a melhoria da qualidade da educação básica em sua esfera de competência, expressa pelo cumprimento de meta de evolução do Ideb, indicada aos munićípios, ao Distrito Federal e aos estados pelo Ministério da Educação. 
Justamente nesse ponto indagamos se todo esse processo tenha resultado de apenas uma evolução ou de uma ruptura em relação ao período anterior, trazendo à tona um novo patamar para o direito à educação no Brasil (com a sua ampliação para pré-escola, fundamental e médio), por meio de ampliação do papel de coordenação nacional da política por parte da Uniáo que, de coadjuvante, passou a ter papel central ao assumir mais efetivamente sua corresponsabilidade pela educação básica. ${ }^{33}$ É fato que, especialmente na última década, a política de educação passou por mudanças substantivas no seu escopo e abrangência, com inequívoca elevação dos indicadores educacionais. Nossa análise, com foco nos instrumentos de coordenação mobilizados pela União no período, sugere que houve uma revisão de postura do governo federal, indicando a conformaçáo de um novo paradigma orientador da política nacional de educação, inspirando a modelagem dos novos arranjos e instrumentos que caracterizaram o período. ${ }^{34}$ No entanto, há que se reconhecer que a questão sobre se isso foi resultado de uma ressignificação dos objetivos da política - mudança de terceira ordem nos termos de Hall (1993) -, ou se constituiu etapa consequente da universalização da oferta do ensino fundamental (mudança de segunda ordem), é algo que ainda deve ser mais pesquisado, por meio, por exemplo, da análise das ideias mobilizadas no redesenho dos programas do MEC nesse período.

\section{NOTAS FINAIS}

Como vimos, a Constituiçâo Federal de 1988 forneceu as bases para os arranjos federativos colaborativos, mas deixou em aberto a definição dos instrumentos de coordenação de políticas públicas. No caso da educação, os instrumentos só passaram a se constituir propriamente a partir da segunda metade dos anos 1990 e desde então vêm se aperfeiçoando, revelando um movimento crescente de coordenação federativa, sob o comando da União. A construção do Fundef, marco inicial da coordenação, contou com atuação e empenho da União no seu desenho e aprovação. Entretanto, durante toda a década de 1990, esse processo se caracterizou por avanços e refluxos na condução da política, além de desresponsabilização pela sua efetivação, inspirada, por um lado, pelos movimentos de descentralização/municipalização que inspiraram o processo constituinte e, de outro, pelos princípios neoliberais e gerencialistas que marcaram a segunda metade da década de 1990, fragilizando o desempenho do papel supletivo e redistributivo da União. O novo século iniciou, portanto, com a necessidade de avançar na agenda da redução das assimetrias para equalizar as oportunidades educacionais para qualquer aluno em qualquer lugar do país.

33. Gomes, Silva e Costa (2019) afirmam, a partir da análise das despesas em educação no período 1995 a 2016, que "é notável a continuidade da estratégia de coordenação nacional do gasto em educação por meio de regulamentação do governo federal tanto nos governos do PSDB quanto do PT. A diferença é que nos governos do PSDB o esforço de crescimento do gasto em educação básica esteve restrito a formulas que induzissem os governos subnacionais a isto, enquanto nos governos do PT, esta estratégia foi associada ao aumento também da participação da União no gasto nacional em educação".

34. Segatto e Abrucio falam em maior ativismo da União (2016, p. 3, grifo nosso). Saviani fala em dinamismo do MEC (2007, p. 1251, grifo nosso). 
A partir da segunda metade dos anos 2000, é possível observar um segundo movimento de fortalecimento da coordenação federal, que revela não apenas o aprimoramento dos instrumentos de coordenaçáo, mas também uma mudança de postura por parte da União, que passa a ocupar maior protagonismo na condução da política. Nesse sentido, a análise dos instrumentos de coordenação mobilizados a partir da criação do Fundeb sugere que o esforço de coordenação federativa empreendido pela União a partir de então não se limitou à intensificação do movimento experimentado durante os anos 1990, mas corrobora com a tese de Gomes, Silva e Costa (2019), de que teria havido uma inflexão e ressignificação da condução da educação básica. Ainda que essa tese - sugestiva de uma mudança de terceira ordem na visão de Hall (1993) - deva ser confirmada por estudos mais robustos a respeito do desenho e resultado das açóes e programas federais que informam a política, a análise dos instrumentos permite verificar claramente na postura do governo federal uma disposição diferenciada em ampliar sua participação e responsabilidade nos arranjos e instrumentos de coordenação federativa.

A natureza dos instrumentos e o papel reservado ao governo central nos arranjos, a partir de 2006, revelam opçóes discricionárias pela ampliação dos espaços de atuação e assunção de responsabilidades. Consideramos portanto que as principais mudanças na postura do governo federal - materializadas pela criação do PDE e respectivos instrumentos de coordenação mobilizados a partir de 2006 - não se devem apenas à atribuição de coordenação da política imposta pela Constituição mediante a $\mathrm{EC}$ no $14 / 1996$ e LDB, mas também se viabilizam pelas reformas posteriores - de 2006 e 2009 - que ampliaram o conteúdo do direito à educação e o aporte de recursos federais na política, sem que necessariamente fosse necessário fazer alterações formais nas competências da União.

Resta saber se a maior coordenação colocou o Brasil no rumo certo com destino a um universalismo com qualidade e equidade. Há, de fato, muitos indicadores positivos sobre a expansão das matrículas em direção à universalização da educação básica, como, por exemplo, o crescimento rápido e acentuado das matrículas em creche, que no período 2008-2016 alcançaram 90,2\% das crianças de 4 a 5 anos, segundo dados do Censo da Educação Básica. Os indicadores de qualidade, como o Ideb, também revelam que, de maneira geral, avançamos muito em termos de resultados educacionais, especialmente nos anos iniciais do ensino fundamental (Inep, s. d.). No entanto, dados sobre manutenção das desigualdades ainda mostram desafios e indicam que, inobstante os esforços de padronização e uniformização de parâmetros de qualidade, os brasileiros ainda acessam os serviços educacionais de forma heterogênea a depender, entre outros fatores, da renda familiar ou do local onde estấo, de modo que a equalização das oportunidades educacionais ainda é um objetivo a ser perseguido. ${ }^{35}$

35. Dados da PNAD/IBGE de 2015 indicavam que enquanto apenas $6 \%$ das crianças de 4 a 5 anos pertencentes às famílias 20\% mais ricas estavam fora da escola, esse percentual atingia 20,2\% das famílias mais pobres. Essa distância também se verificava em relação às regiões brasileiras: $28,7 \%$ das crianças de 4 a 5 anos da região Norte não frequentavam a escola, enquanto no Sudeste eram apenas $11,5 \%$. 
O que faltaria para avançar mais nesse aspecto? O movimento de coordenação do governo federal foi insuficiente e deixou brechas para desenvolvimentos não equitativos? Ou, do contrário, a postura centralizada e hierárquica adotada pelo MEC nesse período teria comprometido a autonomia, o empenho e o desenvolvimento de capacidades dos demais entes federados, inviabilizando soluçóes flexíveis e mais adaptadas às realidades locais? $\mathrm{E}$, nesse caso, como assegurar a construção de instrumentos mais permeáveis às demandas dos entes, sem perder de vista os parâmetros nacionais?

Ainda a respeito de um arranjo federativo mais negociado e menos centralizado não se pode furtar do debate acerca da instituição do Sistema Nacional de Educação (SNE), previsto no art. 13 da Lei do PNE como responsável pela articulação entre os sistemas de ensino para efetivação das diretrizes, metas e estratégias do Plano Nacional de Educação. Caso não sejam bem calibradas, as instâncias de pactuação federativa previstas nos projetos de lei complementar sobre o $\mathrm{SNE}^{36}$ podem transformar esses espaços de negociação em meras instâncias homologatórias de decisóes previamente tomadas pela burocracia federal ou, por seu turno, se constituir em espaços de disputa de interesses e dispersão da política, enfraquecendo o movimento de coordenação recentemente inaugurado, antes mesmo que suas estratégias sejam testadas e os resultados analisados.

\section{REFERÊNCIAS}

ABRUCIO, F. L. A coordenação federativa no Brasil: a experiência do período FHC e os desafios do governo Lula. Revista de Sociologia e Política, n. 24, p. 41-67, 2005.

- A dinâmica federativa da educação brasileira: diagnóstico e propostas de aperfeiçoamento. In: OLIVEIRA, R. P.; SANTANA, W. (Orgs.). Educaçáo e federalismo no Brasil: combater desigualdades, garantir a diversidade. Brasília: Unesco, 2010.

ARAÚJO, G. C. Direito à educação básica: a cooperação entre os entes federados. Retratos da escola, Brasília, v. 4, n. 7, p. 231-243, jul./dez. 2010.

ARRETCHE, M. Federalismo e relaçóes intergovernamentais no Brasil: a reforma de programas sociais. Dados, v. 45, n. 3, p. 431-458, 2002.

. Federalismo e políticas sociais no Brasil: problemas de coordenação e autonomia. Sáo Paulo em Perspectiva, v. 18, n. 2, p. 17-26, 2004. 
Quem taxa e quem gasta: a barganha federativa na federação brasileira. Revista de Sociologia e Política, n. 24, p. 69-85, 2005.

. Estado federativo e políticas sociais: determinantes da descentralização. 3a. ed. Rio de Janeiro: Revan, 2011.

. Conclusóes. In: ARRETCHE, M. (Org.) Trajetórias das desigualdades. São Paulo: Unesp; CEM, 2015.

ARRETCHE, M.; VASQUEZ, D.; GOMES, S. As relações verticais na Federação: explorando o problema da descentralização. In: ARRETCHE, M. (Org.). Democracia, federalismo e centralizaçáo no Brasil. Rio de Janeiro: FGV; Fiocruz, 2012.

BACHUR, J. P. Federalismo fiscal, atribuições fiscais constitucionais equalização regional: EUA, Alemanha e Brasil em perspectiva comparada. Revista do Serviço Público Brasília, v. 56, n. 4, p. 377-401, out./dez. 2005.

BRASIL. Constituição da República Federativa do Brasil. Diário Oficial da Uniáo, Brasília, v. 126, n. 191, 5 out. 1988.

. Lei Federal no 10.172, de 9 de janeiro de 2001. Aprova o Plano Nacional de Educação - PNE e dá outras providências. Diário Oficial da União, Brasília, 10 jan. 2001.

. Ministério da Educação. O Plano de Desenvolvimento da Educação razóes, princípios e programas. Brasília: MEC, 2007.

. Ministério da Educação. Termo de Adesão ao Plano de Metas Compromisso Todos pela Educaçáo. Brasília, 2007a. Disponível em: http://portal. mec.gov.br/arquivos/pdf/par_padrao.pdf

. Ministério da Educação. Secretaria de Educação Básica. Compromisso Todos pela Educaçáo: passo a passo - 2007. Brasília: SEB/MEC, jun. 2008.

Ministério da Educação. Conselho Nacional de Educação. Parecer da Câmera de Educação Básica do CNE nº 8/2010. Estabelece normas para aplicação do inciso IX do artigo $4^{\circ}$ da Lei no 9.394/96 (LDB), que trata dos padróes mínimos de qualidade de ensino para a Educação Básica pública. Brasília, 5 maio 2010.

. Ministério da Educação. Sinopse das ações do Ministério da Educação. Brasília, set. 2011.

. Lei Federal no 13.005, de 25 de junho de 2014. Aprova o Plano Nacional de Educação - PNE e dá outras providências. Diário Oficial da Uniáo, Brasília, 26 jun. 2014.

. Ministério da Educação. Fundo Nacional de Desenvolvimento da Educação. Ministério do Planejamento, Desenvolvimento e Gestão. Secretaria de Gestão 
de Pessoas e Relações do Trabalho no Serviço Público. Nota Técnica Conjunta no 01 /2016/FNDE/MEC/SEGRT/MP. Brasília, 2 dez. 2016. Disponível em: <https://bit.ly/2N5qQ7S>.

CAMINI, L. A política educacional do PDE e do Plano de Metas Compromisso Todos pela Educação. Revista Brasileira de Política e Administraçáo da Educação, Goiânia, v. 26, 2010.

CRUZ, R. E. Federalismo e financiamento da educação: a política do FNDE em debate. In: GOUVEIA, A. B.; PINTO, J. M. R.; CORBUCCI, P. R. (Orgs.). Federalismo e Políticas Educacionais na Efetivação do Direito à Educaçáo no Brasil. Brasília: Ipea, 2011.

CUNHA, C. et al. (Orgs.). O sistema nacional de educação: diversos olhares 80 anos após o Manifesto. Brasília: MEC/Sase, 2014.

. (Orgs.). O MEC pós-Constituição. Brasília: Liber Livro, 2016.

CURY, C. R. J. Sistema Nacional de Educação: desafios para uma educação igualitária e federativa. Educaçáo e Sociedade, Campinas, v. 29, n. 105, p. 1187-1209, set./dez. 2008.

DOURADO, L. F. Avaliação do plano nacional de educação 2001-2009: questóes estruturais e conjunturais de uma política. Educaçáo e Sociedade, Campinas, v. 31, n. 112, jul./set. 2010.

DRAIBE, S. As políticas sociais brasileiras: diagnósticos e perspectivas. In: IPEA - INSTITUTO DE POLÍTICA ECONÔMICA APLICADA. Para a década de 90: prioridade e perspectivas de políticas públicas - volume 4: políticas sociais e organização do trabalho. Brasília: Ipea, 1989.

FARENZENA, N. Políticas de assistência financeira da Uniāo no marco das responsabilidades (inter)governamentais em educação básica. In: GOUVEIA, A. B.; PINTO, J. M. R.; CORBUCCI, P. R. (Orgs.). Federalismo e políticas educacionais na efetivaçáo do direito à educaçáo no Brasil. Brasília: Ipea, 2011.

FERNANDES, F. C. Entrevista: A Conferência Nacional de Educação (Conae) e o Plano Nacional de Educação (PNE). Educaçáo e Sociedade, Campinas, v. 31, n. 112, jul./set, 2010.

FERNANDES, R.; GREMAUD, A. P. Avaliaçáo da qualidade da educaçáo no Brasil. São Paulo: Fundação Santillana: Inep, 2009.

FRANZESE, C. Federalismo cooperativo no Brasil: da constituição de 1988 aos sistemas de políticas públicas. 2010. Tese (Doutorado) - Escola de Administração de Empresas de São Paulo, Fundação Getúlio Vargas, São Paulo, 2010. 
GOMES, S.; SILVA, A. L. N.; COSTA, F. Governos partidários e políticas educacionais no Brasil do século XXI: a eficácia da democracia. In: ARRETCHE, M.; MARQUES, E.; FARIA, C. A. P. de. (Orgs.). As políticas da política: desigualdades e inclusão nos governos do PSDB e do PT. 1. ed. São Paulo: Editora Unesp, 2019. GRIN, E. J. Rotas federativas para a promoçáo capacidades estatais municipais: uma análise da experiência brasileira. Tese (Doutorado em Administração Pública e Governo) - Escola de Administração de Empresas de São Paulo, FGV, 2016.

HADDAD, S.; CARVALHO, L.; SARAIVA, S. Uma avaliaçáo da participaçáo da sociedade civil e da colaboraçáo interministerial do Plano de Desenvolvimento da Educação (PDE). Estudo de Caso Brasil 2008. São Paulo: Açâo Educativa, 2008, p. 16.

HALL, P. A. Policy paradigms, social learning, and the State: the case of economic policymaking in Britain. Comparative politics, v. 25, n. 3, p. 275-296, 1993.

IPEA - INSTITUTO DE POLÍTICA ECONÔMICA APLICADA. Políticas Sociais: acompanhamento e análise. Brasília: Ipea, 2009. (Boletim de Políticas Sociais, n. 17).

Políticas Sociais: acompanhamento e análise. Brasília: Ipea, 2015. (Boletim de Políticas Sociais, n. 23).

JACCOUD, L.; VIEIRA, F. Federalismo, integralidade e autonomia no SUS: desvinculação da aplicação de recursos federais e os desafios da coordenação. Rio de Janeiro: Ipea, 2018. (Texto para Discussão, n. 2399).

LOTTA, G.; GONÇALVES, R.; BITELMAN, M. A coordenação federativa de políticas públicas: uma análise das políticas brasileiras nas últimas décadas. Cadernos Gestáo Pública e Cidadania, v. 19, n. 64, 2014.

OLAIK, L. G.; MEDEIROS, J. J. Instrumentos governamentais: reflexôes para uma agenda de pesquisas sobre implementação de políticas públicas no Brasil. Revista de Administraçáo Pública, Rio de Janeiro, v. 45, n. 6, p. 1943-1967, nov./dez. 2011.

OLIVEIRA, V.; LOTTA, G. S. Qualificando a recentralização: repasses e relações intergovernamentais no Brasil. In: ENCONTRO ANUAL ANPOCS, 38, Caxambu, Minas Gerais, 2014. Anais. São Paulo: Anpocs, 2014.

OLIVEIRA, R. P.; SOUSA, S. Z. O federalismo e sua relação com a educação no Brasil. In: OLIVEIRA, R. P.; SANTANA, W. (Orgs.). Educaçáo e federalismo no Brasil: combater desigualdades, garantir a diversidade. Brasília: UNESCO, 2010. PINTO, J. M. R. Federalismo, descentralização e planejamento da educação: desafios aos municípios. Cadernos de Pesquisa, v. 44, n. 153, jul./set. 2014. 
PINTO, J. M. R.; CARA, D.; ARAÚJO, L. Por que a Uniáo deve complementar o CAQi no PNE? São Paulo: Fineduca, 2013. (Nota Técnica, n. 1/2013).

SANTOS, F. G. M.; ALMEIDA, A. Mobilidade do capital, atores de veto e redistribuiçáo na América Latina durante a virada à esquerda. Brasília: Ipea, 2017. (Texto para Discussão, n. 2325).

SAVIANI, D. O Plano de Desenvolvimento da Educação: análise do projeto do MEC. Educação \& Sociedade, v. 28, n. 100, p. 1231-1255, 2007.

SEGATTO, C. I. O papel dos governos estaduais nas políticas municipais de educaçáo: uma análise dos modelos de cooperação intergovernamental. 2015. Tese (Doutorado em Administração Pública e Governo) - Escola de Administração de Empresas de São Paulo, Fundação Getúlio Vargas, São Paulo, 2015.

SEGATTO, C.; ABRUCIO, F. A cooperação em uma federação heterogênea: o regime de colaboração na educação em seis estados brasileiros. Rev. Bras. Educ. [online]. 2016, v. 21, n. 65, p. 411-429.

SOUZA, C. Federalismo, desenho constitucional e instituições federativas no brasil pós-1988. Revista de Sociologia e Política, Curitiba, 24, p. 105-121, jun. 2005.

. Coordenaçáo de políticas públicas. Brasília: Enap, 2018.

SUMIYA, L. A. Governo federal em contexto de descentralizaçáo: os programas de formação de professores do ensino fundamental (1995-2002). 2006. Dissertação (Mestrado em Administração Pública e Governo) - Escola de Administração de Empresas de São Paulo, Fundação Getúlio Vargas, São Paulo, 2006.

SUMIYA, L. A.; FRANZESE, C. Relaçôes intergovernamentais: o Fundef e a municipalização do Ensino fundamental no Estado de São Paulo. In: VIEITEZ, C. G.; BARONE, R. E. M. Educaçáo e políticas públicas: tópicos para o debate. São Paulo: Junqueira \& Marin Editores, 2007.

TERTO, D. C.; CASTRO, A. M. D. A.; SANO, H. O Plano de Açóes Articuladas no contexto do federalismo brasileiro: instrumento de colaboração intergovernamental? Educaçáa, v. 40, n. 3, p. 396-404, Porto Alegre, set./dez. 2017. 
